Proceedings of the International Scientifical Conference. Volume II: Social and Special pedagogy; Health and Sport; Overviews.

\title{
IMPLEMENTATION OF INCLUSIVE APPROACH IN EDUCATION OF LEARNERS WITH SPECIAL NEEDS IN LATVIA
}

\section{Iekl̦aujošās pieejas īstenošana apmācāmo ar speciālām vajadzī bām izglītošanā Latvijā}

\author{
Vija Guseva \\ Daugavpils University, Latvia \\ Email: vija.guseva@du.lv
}

\begin{abstract}
The present article considers the provision of education for learners with special needs in modernist and postmodernist societies. It emphasizes that inclusive approach in education is a multi-stage process characterized by the following principles: provision of justice and equality, participation and inclusion, guarantee of achievement for all learners including those with special needs.

The aim of the present article is to consider how keeping to the principles of inclusive approach in education initiates changes in the practical work of general education schools in Latvia and other countries having a significant experience of inclusion of learners with special needs, and how these changes lay the way to sustainable education.

The article reflects the theoretical analysis of the normative documents regulating Latvian education policy and the assessment of international research results in accordance with the principles of inclusive approach and settings of sustainable education.
\end{abstract}

Keywords: inclusive approach, sustainable education, learners with special needs.

\section{Introduction}

Until the end of the twentieth century, the dominant offer in educating learners with special needs in Latvia was designing special education programmes in special education establishments. Discussion on the experience of other countries of inclusion of learners with special needs in general education schools and the compatibility of this experience to the situation in the country started after regaining of independence in Latvia in 1991.

As concerns the provision of education for learners with special needs in modernist and postmodernist societies, it is noted that inclusive approach in education is a multi-stage process characterized by clear-cut principles: provision of justice and equality, participation and inclusion, guarantee of achievement for all learners. This makes the aim of our research more particular: to evaluate how keeping to the principles of inclusive approach in education initiates changes in the practical work of general education schools in Latvia and other countries having a significant experience of inclusion of learners with special needs, and how these changes lay the way to sustainable education. The present article reflects the analysis of theoretical studies concerning the following:

- models of education of learners with special needs in modernist and postmodernist societies; 
- principles of justice and equality in the education policy of learners with special needs in Latvia;

- principles of participation and active involvement for the inclusion and sustainable education of learners with special needs;

- inclusive approach in sustainable education: guarantee of achievement for all learners.

\section{Models of education of learners with special needs in modernist and postmodernist societies}

As regards the history of the development of the ideas of inclusion of learners with special needs, it must be noted that already philosophers of the Enlightenment formulated a range of new ideas and visions on accessibility of education for all, thus laying the basis for what in the nineteenth century became a project of democracy and education as a part of modernism. Authors (e.g. Allan, 2004; Wagner, 1994; Vislie, 2006) note that modernism is characterized by a discussion on ideas of freedom, democracy, and equality, yet it must be emphasized that modernism is also marked by a conflict between personality freedom and discipline and control, i.e. individual just cannot be different from others. Social institutions, thus also schools have a comparatively stable set of rules and resources that people may use for their education. Taking into consideration the fundamental duality of modernism, it may be explained why provision of education for learners with special needs in ideas of modernism and the practice of modernist society institutions is carried out within special education. Education opportunities of learners with special needs and their social activity are determined by social relations aspects of modernism: classification of all social phenomena and using this classification in the society emphasizing hierarchy and thus legalizing exclusion (Wagner, 1994). In the western part of Europe the above mentioned processes were in progress until World War II (Wagner, 1994) while in the eastern part and also in Latvia - until the downfall of the USSR.

With the ongoing liberalization of society in Western Europe and the USA, with growing activity of public movements on the rights of people with special needs, the perspective on education were undergoing essential change. Learners with special needs started to be integrated in schools of general education, but as characteristic features of modernism are specialization and professionalism, the idea of a school for all is carried out as two schools under one roof (Vislie, 2006), i.e. learners with special needs learn in separate classes of general education schools being separated from their peers and acquire the content of special education curriculum.

Times of late modernism with their characteristic individualization and pluralism (Wagner, 1994) in the 1960-70s in Western Europe and the USA secure integration of learners with special needs in schools of general education in several ways from which the most widespread one is mainstreaming or placing children with moderate development disorders in forms of general education schools where 
Proceedings of the International Scientifical Conference. Volume II: Social and Special pedagogy; Health and Sport; Overviews. their learning problems are solved by offering a certain amount of educational services while emphasizing the readiness of the particular learner for integration by evaluating the academic knowledge of learners and their emotional readiness as a prerequisite of the integration opportunity (Allan, 2004).

With the decline of the impact of modernist ideas and the growth of postmodernist ones, an international debate has been started to evaluate both the offer of special education and the results of integration, and it is acknowledged that direct or indirect discrimination of a particular school or class undoubtedly cause marginalization of learners with special needs (Ainscow, 1994). The incompatibility of special education most and foremost to the change of beliefs of Western European and US society on education of learners with special needs and their future opportunities gave rise in the 1990s to a new tendency elaborated under the guidance of UNESCO - inclusion of learners with special needs in general education schools and learning in one class together with peers the basic education curriculum (UNECCO, 1994). The phenomenon of societal change is also emphasized manifested in the change of responsibility for people with development disorders: social or custodial responsibility grows into educational responsibility that is manifested in accessibility of general basic education and emphasizes ideas on provision of opportunities for equality, active participation and inclusion of all learners in education (Ainscow, 1994).

Definitions of inclusive approach in education emphasize several aspects characterizing the essence and multifariousness of this process: 1) all learners, also those with expressed development disorders, have equal rights to receive education services and equal, wide opportunities of education together with their peers (UNECCO, 1994); 2) learners are provided an opportunity of complete participation in the process of learning in the classes corresponding to their chronological age in general education schools closest to their place of residence that execute general education curricula (Booth \& Ainscow, 2002); 3) individual needs of each learner are respected and observed in the teaching practice (Salisbury \& Strieker, 2003); 4) each learner's potential is studied and assessed (Booth \& Ainscow, 2002; Stewart, 2000); 5) positive expectations from the perspective of other learners, teachers, school administration, parents become a part of school culture to foster social interaction of learners with special needs and their active participation in school community in all aspects of school life (Stewart, 2000); 6) harmonizing of teaching practice with the societal needs to prepare learners for productive life of rightful community members (Salisbury \& Strieker, 2003).

Values and ethicality as a conceptual understanding of sustainable development are contextually dependent and may be implemented in several ways (Ryden, 2009). Education undergoes changes and becomes sustainable on the basis of the general manifestations of sustainable development, i.e. becoming more democratic, eco-centric, socially responsible and inclusive (Sterling, 1998). Definitions of sustainable development include the ideas of inclusion of learners with special needs in the system of general education: presence of democracy, 
equality, and social justice in all ongoing educational processes, dialogue and complementarity of the involved, observance of versatility and multidimensionality respecting the various needs (Salīte \& Pipere, 2006; Ryden, 2009), civic participation activity on the basis of the acquired knowledge and skills improving the life quality of one's own and other generations (Baltija 21, 2003). Hence, along with a certain change of society beliefs, inclusion of learners with special needs in general basic education has appeared as one of the manifestations of sustainable development of the society.

In this context the holistic view characteristic of the inclusive approach on problem solving is set, and this unity determines the principles of inclusive approach (UNESCO, 2005): to secure equal rights to education for all learners, manifold opportunities of their participation and involvement, achievement for learners with special needs and their peers in common acquisition of the basic education curriculum.

\section{Principles of justice and equality in the education policy of learners with special needs in Latvia}

Rights of learners with special needs to learn together with their peers in schools of general education and provision of these rights with concrete resources are explained and put to practice by a number of international and national normative documents.

As regards the results of the implementation of the inclusive approach in education over recent 20 years, it must be noted that documents regulating education policy in Latvia mark the competence of local government (as a founder of education establishments) as entailing the task of providing the right of learners to acquiring education in the school closest to their place of residence according to a free choice of parents and children (Act on Education, 1998; Education development positions for 2007-2013, 2006; Act on Local Governments, 1994) as well as the right of learners with special needs to acquiring education in general education schools in accordance with learners' age and needs (Act on Education, 1998; Act On Medical and Social Protection of the Disabled, 1992). It is emphasized that learners with special needs have ... equal rights to active life, developing and acquiring general ... education in accordance with their physical, spiritual abilities and preferences ... like any other child (Act on the Protection of Children's Rights, 1998). Act on Education (1998) states that in Latvia education establishments have autonomy in elaboration and execution of education programmes including also special education programmes, social correction education programmes (Act on Education, 1998). Special education, as stated in the Act on General Education (1999), provides opportunities and conditions for learners with special needs in their acquiring education matching their health condition, abilities and development level in any education establishment (special school, special class or general education class with learners with special needs) simultaneously providing learners with educational and psychological correction, 
Proceedings of the International Scientifical Conference. Volume II: Social and Special pedagogy; Health and Sport; Overviews. preparing them for working and living in society (Act on General Education, 1999). It is also specified that special education is an adapted form of general education (Education development positions..., 2006). Act on General Education (1999) specifies that general basic education establishments having a corresponding equipment, on the basis of state or local government educational-medical commission resolution, may integrate learners with special needs: any education establishment may open classes for learners who need social or educational correction.

Comparatively recent documents, e.g. Education development positions for 2007-2013 (2006) point out that one of the major issues of Latvian education policy is integration of learners with special needs in the system of general education. It is stated that basically in parallel with the executed programmes of educational correction and catch-up development, methodologies must be elaborated for working with learners having a different level of prior knowledge and learning difficulties. They also emphasize the urgency of orientation towards the improvement of special school environment, special education programmes and methodological materials (Education development positions..., 2006). Though normative documents envisage an opportunity for learners with special needs to gain education in schools of general education, the families with these children usually choose special schools. This choice is determined not only by the previous tradition of education learners with special needs in special schools but also the limited economic resources of some schools of general education to respond to the needs of all learners.

In recent years in international forums the implementation of the inclusive approach in education in Latvia has been defined as a priority of education policy and it is stated that educating of learners with special needs takes place in two ways - by mastering general education programmes or special education ones (Kokse, 2008). Hence, in the academic year 2007/2008, 625 (37\%) of all learners with special needs going to schools of general education mastered the content of general basic education curriculum (Rozenvalds \& Ijabs, 2009). This experience of inclusion of this relatively small part of learners is under formation in individual schools in Latvia (Nīmante, 2008), though in diverse reports this practice is related to integration of learners with special needs (Kokse, 2008; Rozenvalds \& Ijabs, 2009).

According to theoreticians of the inclusive approach in education (e.g. Booth $\&$ Ainscow, 2002), the assessment of the quality of the inclusion process is based on certain criteria. One of them is precise definition of notions determining a united conception of the process directedness. Evaluation of normative documents leads to the conclusion that in Latvia one may observe relatively fused boundaries between the understanding and use of notions integration and inclusion but it is also noted that terminology is in the process of specifying along with the particularization of the understanding of the inclusive approach in education (Nimante, 2008). 
It must be noted that also the experience of individual school in the implementation of the inclusive approach, as is the case in Latvia, is a significant gain, as, according to Ainscow (2004), positive experience in inclusive approach may be formed in the framework of individual schools, it may be an initiator of later and more comprehensive changes. The inclusive practice implemented by individual schools, if it becomes a part of systemic change process in education policy, simultaneously becomes a manifestation of sustainable education (Ryden, 2009). Hence it may be concluded that, to facilitate the development of the inclusive approach in Latvia, there is a need for summarizing and evaluating the experience of the inclusion of learners with special needs in schools of general education.

\section{Principles of participation and active involvement for the inclusion and sustainable education of learners with special needs}

In international discussions at the academic and educational level, basic ideas of the inclusive approach in education are emphasized that embody the standpoints of sustainable education: presence, participation, involvement, cooperation (Ainscow, 1994; 2004; Booth, \& Ainscow, 2002; UNESCO, 2005).

Parents, when choosing a school for a child with special needs, note the formation of social contacts as an important factor of the child's inclusion in peer group: formation of friendly relations, learning to react adequately and successfully deal with diverse situations by participation in common activities of different kind (Frostad \& Pijl, 2007).

The results of the comparative research (Forstad \& Pijl, 2007; Koster, Pijl, Houten \& Nakken, 2007; Mand, 2007) produced in 2006 in Germany, the Netherlands, and Norway reveal an important idea for planning and organizing the inclusive educational practice - if a learner with special needs successfully masters the skills of cooperation, his/her relations with peers provide a positive impetus for his/her general development. The research results include several essential conclusions.

First, the cause of avoiding cooperation with peers with special needs is not their being different. However, at the initial stage of the research it was admitted that peers in special schools might have more successful relations, due to all learners having similar development peculiarities - special needs, as compared to heterogeneous ability classes where learners with special needs learn together with their peers. The research outcomes prove that there exists an equally significant correlation between insufficient acquisition of cooperation skills by learners with special needs and their status in class both in special and general education school these learners are cast out in both social environments. According to the authors of the research, homophily is related to diverse human qualities and it cannot be linked with just one difference between people (e.g. special needs), but also age, gender, race, education level, values, interests as well as aptitude of cooperation skills. Learners with special needs in their peers' understanding may not match any 
Proceedings of the International Scientifical Conference. Volume II: Social and Special pedagogy; Health and Sport; Overviews. of these qualities and thus become outcasts (Frostad \& Pijl, 2007) both in general education and special schools.

Second, being situated in a particular social environment does not solve problems of interpersonal relations of learners with special needs. If the learner with special needs is constantly excluded by his/her peers due to poor cooperation skills, this attitude just enhances deviant behaviour, thus impeding any positive change both in the undesirable behaviour of these learners and the improvement of their cooperation skills (Mand, 2007).

Third, it is concluded that just for a part of learners the impediment of their acquisition of cooperation skills is related to their limited physical, sensory and/or intellectual abilities, while for others the reason of failure is not the inability to master cooperation skills but the fact that peers do not change their attitude and behaviour and thus their classmates do not have an opportunity to practice their newly acquired skills of cooperation, thus they lose sense and quality (Koster, Pijl, Houten \& Nakken, 2007).

Fourth, it is concluded in the research that $20-25 \%$ of learners with special needs are not equally accepted in all small peer groups existing in classes of general education school. Yet the research leads to the conclusion that, if a learner with special needs develops stable friendly relations with at least one peer in class, it essentially and positively affects his/her status not only in the small group represented by the friend but also reduces the possibility of negative status of this learner in other small peer groups (Mand, 2007).

Fifth, the research makes it possible to conclude that learners' emotional and social development is not essentially determined by their particular status in class as comparatively the social and emotional development of learners with special needs just slightly lags behind that of their peers. In the cognitive sphere, evaluating learners' personal growth dynamic indications, more rapid development is observed with learners with special needs in comparison to their peers (Koster, Pijl, Houten \& Nakken, 2007).

Several researchers (e.g. Koster, Pijl, Houten \& Nakken, 2007) ascertain that junior school age is most favourable for the formation and consolidation of the cooperation skills of all learners. It is concluded that purposive guidance of the cooperation between learners with special needs and their peers by getting them involved in cooperative activities facilitates successful inclusion (Frostad \& Pijl, 2007), as it is positively enhanced by the objective sense of justice containing the principle of equality, accomplishment and benevolence that has already been formed for junior school age children (Krastina \& Pipere , 2004).

The outcomes of the above mentioned research lead to the conclusion that there is no justification for planning specific, peer-separated activities for learners with special needs aimed at equalizing the different levels of their cooperative skills, but instead learners ought to be given an opportunity to acquire these skills in common activities with their peers whose benevolent attitude will be the most 
significant stimulus for learning cooperation skills, their application and improvement as well as the basis for common and individual achievement.

\section{Inclusive approach in sustainable education: guarantee of achievement for all learners}

Studies on education issues produced in recent decades after evaluating the observance of the principle characterizing the inclusive approach, i.e. guarantee of achievement for all learners, lead to the conclusion that education of learners with special needs in general education schools is becoming more adjusted and varied (Frostad \& Pijl, 2007; Vislie, 2006). Trends of work of a teacher implementing the inclusive approach are the following: first, securing the execution of the contemporary society's progressive view on equality of learners with special needs; second, demonstrating practice and improvement of cooperation; third, providing maximum and manifold development of all heterogeneous ability class learners. If the provision of the first trend of work is supported by normative documents regulating education, then responsibility for a successful cooperation between learners with special needs and their peers as well as for academic achievement of all learners at present lies just on the teacher's professional skills, initiative, and it is their own personal responsibility (Nīmante, 2008; UNESCO, 2005).

Regarding the such a multilayered action by the teacher in a systemic perspective, Skrtic (1995) notes that changes in social organizations like school take place only in case their participants give an opportunity for constructing the significance of changes - by investigating, consulting, discussing. Teachers in inclusive schools must develop the understanding of the importance of the inclusive approach as a justification for school transformation (Vislie, 2006), as underdeveloped, unstable understanding of the importance of the ideas of inclusion may cause teachers' opposition to changes, unwillingness to accept the new school policy and implement the new learning strategies (Skrtic, 1995). Only when teachers have made sure and have assessed their existing thinking and cooperation models and start to focus on thinking and cooperating differently - in a more complete way, they start changing school and these changes back up the growing assurance and success (Vislie, 2006) securing the formation of a systemic approach in order to teach each learner in the best possible way (Skrtic, 1995).

Schools must change to become places where teachers make creative plans, learn and cooperate (Skrtic, 1995), where teachers are aware of and implement the idea of inclusion, as teacher of general education school is the one who is responsible for the everyday achievement of learners with special needs (UNESCO, 2005). Thus we may conclude that heterogeneous ability class is a powerful determining factor for changes in teaching and learning practices within a school. Hence, purposive orientation at guaranteeing achievement for learners with special needs and their peers by implementing the inclusive approach is related to the context of the sustainable development of the whole society: it is also a goal- 
Proceedings of the International Scientifical Conference. Volume II: Social and Special pedagogy; Health and Sport; Overviews. oriented focusing on changes determined by school/class as a social ecosystem (Ryden, 2009).

Ainscow (2004) notes that experience models of inclusive schools are impossible to copy or transfer to another place or situation; likewise it is not to be expected that schools will change just by proclaiming new values and new policies. He emphasizes that new experience must be accumulated in the process of change that would secure the development of ideas, values and along with those also changes at schools.

Hence, to secure achievement opportunities both for learners with special needs and their peers, it is necessary for teachers and learners to be aware of what they are doing when teaching or learning. Understanding of problems and needs is one of the major features of sustainable education that ought to be implemented in every education establishment in Latvia.

\section{Conclusion}

Consideration of the further improvement of ideas of inclusion, according to values accepted in postmodernist society, change of public opinions regarding the role of people with special needs in society, their education opportunities, leads to the conclusion that the inclusive approach in education of learners with special needs is crystallized in society as one of the manifestations of sustainable development of society and sustainable education.

Analysis of normative documents regulating Latvian education policy brings out the fact that they emphasize guaranteeing human rights, state the responsibility of society on the whole as well as the responsibility attributed to particular administrative structures, institutions, professionals, parents and/or children. However, the terminology used in these documents emphasizes integration as a leading solution of education issues of learners with special needs in a pragmatic, politically neutral form of education service without indicating essential changes in the system of education and educational institutions or the formation of sustainable education.

Though it may be noted that terminology is being improved also in the international research along with the particularization of the understanding of the inclusive approach in education, the analysis of the normative documents regulating Latvian education policy reveals rather fluid boundaries between the understanding and use of the notions integration and inclusion. Lack of such precise definitions is a factor of risk in the implementation of the inclusive approach in education in Latvia.

Internationally produced research shows that the physical presence of learners with special needs in a class of general education is just the beginning of the process but not the completion of ideas of inclusion. The task of parents and teachers is to facilitate cooperation between learners with special needs and their peers, thus providing a positive impetus for the development of their sense of security and belonging, preventing them being cast out or ignored in the class. As 
the possibilities of cooperation between learners with special needs and their peers have received little theoretical interest in Latvia so far, when planning and organizing inclusive teaching practice, teachers should use the ideas drawn from the research produced in other countries.

For further improvement of the education of learners with special needs proceeding from the principles characteristic of the inclusive approach - securing justice and equality, implementing participation and inclusion, guaranteeing achievement for all learners - twofold changes are to be planned at schools: 1) at the individual level - cooperation between learners with special needs and their peers and 2) at the level of the system of education and/or school or institutional level - changes in securing sustainable education. Hence the tasks emerge that need to be taken up by each educational establishment in Latvia: understanding problems and needs that is one of the essential features of sustainable education.

\section{Bibliography}

1. Act on Education. (1998). Latvijas Vēstnesis, 343/344 (1404/1405), 17.11.1998.

2. Act on General Education. (1999). Latvijas Vēstnesis, 213/215 (1673/1675), 30.06.1999.

3. Act on Local Governments. (1994). Latvijas Vēstnesis, 61(192), 24.05.1994.

4. Act on Medical and Social Protection of the Disabled. (1992). Zinotājs, 42, 29.10.1992.

5. Act on the Defence of Children's Rights. (1998). Latvijas Vēstnesis, 199/200 (1260/1261), 08.07.1998.

6. Ainscow, M. (1994). Special needs in the classroom: a teacher's guide. London: UNESCO Jessica Kingsley.

7. Ainscow, M. (2004). Education for All: the challange of inclusion. Notes, School of Education. M: University of Manchester.

8. Allan, J. (2004). Deterritorializations: Putting postmodernism to work on teacher education and inclusion. Educational Philosophy and Theory, 36 (4), 45-56.

9. Baltija 21E (2003). An Agenda 21 for Education in the Baltic Sea Region. Retrieved May 5, 2010 from http://www.baltic21.org/attachments/no22002 education sector_report.pdf.

10. Booth, T. \& Ainscow, M. (2002). Index for inclusion: developing learning and participation in schools. Centre for Studies on Inclusive Education supporting inclusion, challenging exclusion. Retrieved February 6, 2010 from http://www.csie.org.uk/ publications/inclusion-index-explained.shtml

11. Education development positions for 2007-2013 (2006) Latvijas Vēstnesis, 156(3524), 29.09.2006.

12. Frostad, P. \& Pijl, S. J. (2007). Does being friendly help in making friends? The relation between the social position and social skills of pupils with special needs in mainstream education. European Journal of Special Needs Education, 22(1), 15-30.

13. Koķe, T. (2008). Ziņojums UNESCO par iekļaujošo izglītību Latvijā [Report UNESCO on Inclusive Education] Retrieved February 11, 2011 from http://www.ibe.unesco.org/ fileadmin/user_upload/Policy_Dialogue/48th_ICE/Guide_NR08_final_eng.pdf

14. Koster, M., Pijl, J., Houten E. \& Nakken, H. (2007). The social position and development of Pupils with SEN in mainstream Dutch primary schools. European Journal of Special Needs Education, 22(1), 31-46.

15. Krastiņa, E. \& Pipere, A. (2004). Mācību sasniegumu pašizvērtēšsana. [Self-evaluation of Academic Achievement] Rīga: RaKa. 
Proceedings of the International Scientifical Conference. Volume II: Social and Special pedagogy; Health and Sport; Overviews.

16. Lindroos, P. \& Melen-Paaso, M. Aspects of Education for Sustainable Development: International and Regional Policies and Strategies. Environmental Education at Universities, Rīga: LU Akadēmiskais apgāds.

17. Mand, J. (2007). Social position of special needs pupils in the classroom: a comparisonbetween German special schools for pupils with learning difficulties and integrated primary school classes. European Journal of Special Needs Education, 22(1), 7-14.

18. Nīmante, D. (2008). Bērnu ar speciālām un īpašām vajadzībām ieklaujošās izglìtības vēsturiskā attīstība. [The Historical Development of the Inclusive Education of Children with Special and Specific Needs] Promocijas darbs: Latvijas Universitāte.

19. Ryden, L. (2009). Sabiedrība un vide - kurš atbildīgs? [Society and Environment Who's Responsible?] Environmental Education at Universities, Rīga: LU Akadēmiskais apgāds, 36-51.

20. Rozenvalds, J. \& Ijabs I. (2009). Latvija. Pārskats par tautas attīstību, 2008/2009:Atbildīgums. [Latvia. Review of National Development, 2008/2009: Responsibility.] Rīga: LU Akadēmiskais apgāds.

21. Salisbury,C \& Strieker (2003). Elementary School in Including Students with Severe Disabilities. Pearson.

22. Salīte, I \& Pipere, A. (2006). Aspects of sustainable development from the perspective of teachers. Journal of Teacher Education and Training, 6, 15 - 32.

23. Skrtic, T. M. (1995). Disability and democracy: reconstructing (special) education for postmodernity. New York: Teachers College Press.

24. Sterling, S. (1998). Inspiration! A report and commentary for the Commission on Sustainable Development. Godalming. UK: WWF.

25. Stewart, L. M. (2000). Connecting Regular and Special Education Pathways at the High School Level. Case Studies on Inclusive Education. Summary of doctoral dissertation. Philosophy Department of Educational Psychology. Edmonton: Alberta Spring.

26. UNESCO (1994). The Salamanca Statement and framework for action on special needs education. Paris: UNESCO.

27. UNESCO (2005). Guidelines for Inclusion: Ensuring Access to Education for All. Paris: UNESCO.

28. Vislie, L. (2006). Special education under the modernity. From restricted liberty, through organized modernity, to extended liberty and a plurality of practices. European Journal of Special Needs Education, 21(4), 395-414.

29. Wagner, P. (1994). A sociology of modernity: liberty and discipline. London: Routledge.

This study was supported by ESF project "Support to Implementation of Doctoral Studies at Daugavpils University”, agreement No. 2009/0140/1DP/1.1.2.1.2/09/IPA/VAA/015.

Vija Guseva Daugavpils University,

Faculty of Education and Management

Daugavpils, Parades 1-204, Latvia, LV-5400

Email: vija.guseva@du.lv 